\title{
TEMPO-derived spin labels linked to the nucleobases adenine and cytosine for probing local structural perturbations in DNA by EPR spectroscopy
}

\author{
Dnyaneshwar B. Gophane and Snorri Th. Sigurdsson*
}

\author{
Full Research Paper \\ Address: \\ University of Iceland, Department of Chemistry, Science Institute, \\ Dunhaga 3, 107 Reykjavik, Iceland \\ Email: \\ Snorri Th. Sigurdsson* - snorrisi@hi.is \\ * Corresponding author \\ Keywords: \\ aminoxyl radical; ESR spectroscopy; nitroxide; nucleic acids; \\ site-directed spin labeling (SDSL); spin labels; structure-dependent \\ dynamics
}

Open Access

\author{
Beilstein J. Org. Chem. 2015, 11, 219-227. \\ doi:10.3762/bjoc.11.24 \\ Received: 18 November 2014 \\ Accepted: 15 January 2015 \\ Published: 09 February 2015 \\ This article is part of the Thematic Series "Nucleic acid chemistry". \\ Guest Editor: H.-A. Wagenknecht \\ (c) 2015 Gophane and Sigurdsson; licensee Beilstein-Institut. \\ License and terms: see end of document.
}

\begin{abstract}
Three 2'-deoxynucleosides containing semi-flexible spin labels, namely ${ }^{\mathrm{T}} \mathrm{A},{ }^{\mathrm{U}} \mathrm{A}$ and ${ }^{\mathrm{U}} \mathrm{C}$, were prepared and incorporated into deoxyoligonucleotides using the phosphoramidite method. All three nucleosides contain 2,2,6,6-tetramethylpiperidine-1-oxyl (TEMPO) connected to the exocyclic amino group; ${ }^{\mathrm{T}} \mathrm{A}$ directly and ${ }^{\mathrm{U}} \mathrm{A}$ as well as ${ }^{\mathrm{U}} \mathrm{C}$ through a urea linkage. ${ }^{\mathrm{T}} \mathrm{A}$ and ${ }^{\mathrm{U}} \mathrm{C}$ showed a minor destabilization of a DNA duplex, as registered by a small decrease in the melting temperature, while ${ }^{\mathrm{U}} \mathrm{A}$ destabilized the duplex by more than $10^{\circ} \mathrm{C}$. Circular dichroism (CD) measurements indicated that all three labels were accommodated in B-DNA duplex. The mobility of the spin label ${ }^{\mathrm{T}} \mathrm{A}$ varied with different base-pairing partners in duplex DNA, with the ${ }^{\mathrm{T}} \mathrm{A} \cdot \mathrm{T}$ pair being the least mobile. Furthermore, ${ }^{\mathrm{T}} \mathrm{A}$ showed decreased mobility under acidic conditions for the sequences ${ }^{\mathrm{T}} \mathrm{A} \cdot \mathrm{C}$ and ${ }^{\mathrm{T}} \mathrm{A} \cdot \mathrm{G}$, to the extent that the EPR spectrum of the latter became nearly superimposable to that of ${ }^{\mathrm{T}} \mathrm{A} \cdot \mathrm{T}$. The reduced mobility of the ${ }^{\mathrm{T}} \mathrm{A} \cdot \mathrm{C}$ and ${ }^{\mathrm{T}} \mathrm{A} \cdot \mathrm{G}$ mismatches at $\mathrm{pH} 5$ is consistent with the formation of ${ }^{\mathrm{T}} \mathrm{AH}^{+} \cdot \mathrm{C}$ and ${ }^{\mathrm{T}} \mathrm{AH}^{+} \cdot \mathrm{G}$, in which protonation of N1 of A allows the formation of an additional hydrogen bond to N3 of C and N7 of G, respectively, with $\mathrm{G}$ in a syn-conformation. The urea-based spin labels ${ }^{\mathrm{U}_{\mathrm{A}}}$ and ${ }^{\mathrm{U}_{\mathrm{C}}}$ were more mobile than ${ }^{\mathrm{T}} \mathrm{A}$, but still showed a minor variation in their EPR spectra when paired with $\mathrm{A}, \mathrm{G}, \mathrm{C}$ or $\mathrm{T}$ in a DNA duplex. ${ }^{\mathrm{U}} \mathrm{A}$ and ${ }^{\mathrm{U}} \mathrm{C}$ had similar mobility order for the different base pairs, with the lowest mobility when paired with $\mathrm{C}$ and the highest when paired with $\mathrm{T}$.
\end{abstract}

\section{Introduction}

The knowledge about structures and conformational dynamics of nucleic acids, as well as other biomolecules, is essential to understand their biological functions, including interactions with other molecules. The exact atom-to-atom structural infor- mation can be obtained by X-ray crystallography [1-6] and nuclear magnetic resonance (NMR) spectroscopy [7-12]. Electron paramagnetic resonance (EPR) and fluorescence spectroscopies are nowadays routinely used to study global structures 
and conformational changes under biologically relevant conditions through the determination of intermediate to long-range distances [13-30]. EPR spectroscopy can also give information about the relative orientation of two rigid spin labels [31-35]. Small angle X-ray scattering is also frequently used to study global structures of large molecules and molecular assemblies [36-39].

Local structural perturbations in nucleic acids can be studied with some of the aforementioned techniques. For example, NMR has been used to study hydrogen-bonding interactions [11,40-42], non-native base-pairing properties of nucleobases [43-46] and their dynamics $[42,47,48]$. Fluorescence spectroscopy, using environmentally sensitive fluorescent nucleosides has been used for detection of local structural perturbations [49-57], including the investigation of single-base mismatches [51,54,56,58,59], abasic sites [60] as well as nick sites in duplex DNA [61], and ligand-induced folding of riboswitches $[62,63]$.

Continuous wave (CW) EPR spectroscopy can be used for the determination of structure-dependent dynamics based on the line-shape analysis of the EPR spectra [64-73]. The spin labels for such experiments are attached to the nucleotide via a flexible or a semi-flexible tether, which allows some motion of the spin label independent of the nucleic acid. Spin-label motion is affected by the local surroundings of the label, which in turn is reflected in the shape of the EPR spectra. We have previously used the spin label ${ }^{\mathrm{T}} \mathrm{C}$ [69], containing a 2,2,6,6-tetramethylpiperidine-1-oxyl (TEMPO) moiety conjugated to the exocyclic amino group of $\mathrm{C}$ (Figure 1A), to identify the base to which it is paired with in duplex DNA [69]. In other words, this label could not only distinguish between pairing with guanine and a mismatch but was also able to pinpoint the base-pairing partner. Furthermore, ${ }^{\mathrm{T}} \mathrm{C}$ revealed a flanking-base dependent variation in the EPR spectra, showing that minor structural variations in the local surroundings of a nucleic acid groove can be detected with spin labels by EPR spectroscopy.

Here, we describe the use of an analogous derivative of A, namely ${ }^{\mathrm{T}} \mathrm{A}$, in which a TEMPO moiety is conjugated to the exocyclic amino group of $2^{\prime}$-deoxyadenosine (Figure 1B), to study local perturbations for a purine base in DNA. We show that ${ }^{\mathrm{T}} \mathrm{A}$ can indeed be used to differentiate between different base-pairing partners, albeit not as clearly as ${ }^{\mathrm{T}} \mathrm{C}$. Lower $\mathrm{pH}$ causes noticeable changes in the EPR spectra for ${ }^{\mathrm{T}} \mathrm{A}$, in particular for the ${ }^{\mathrm{T}} \mathrm{A} \cdot \mathrm{G}$ and ${ }^{\mathrm{T}} \mathrm{A} \cdot \mathrm{C}$ mismatches, presumably because of protonation of the base. We have also prepared urea-linked spin-labeled derivatives of 2 '-deoxycytidine $\left({ }^{\mathrm{U}} \mathrm{C}\right)$ and 2 '-deoxyadenosine $\left({ }^{\mathrm{A}} \mathrm{A}\right)$ and incorporated them into DNA duplexes (Figure $1 \mathrm{C}$ and D). These labels provide additional possibilities for hydrogen-bonding through the urea linkage but are also more flexible than ${ }^{\mathrm{T}} \mathrm{A}$ or ${ }^{\mathrm{T}} \mathrm{C}$. In spite of the increased flexibility of ${ }^{\mathrm{U}} \mathrm{C}$ and ${ }^{\mathrm{U}} \mathrm{A}$, inspection of the line-shape of their CW EPR
A

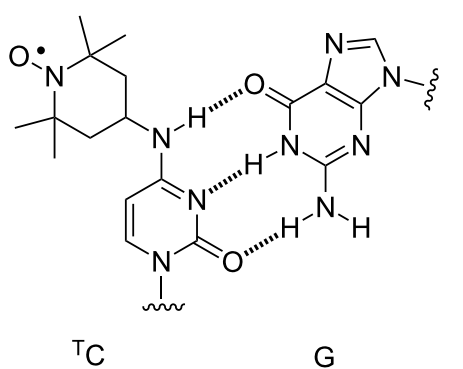

B

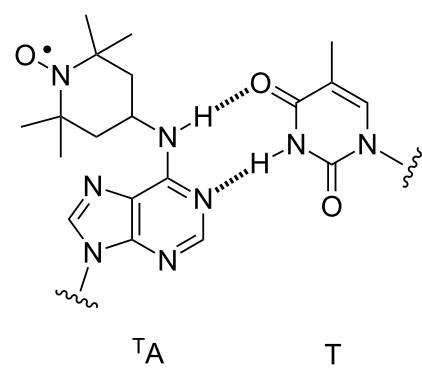

D

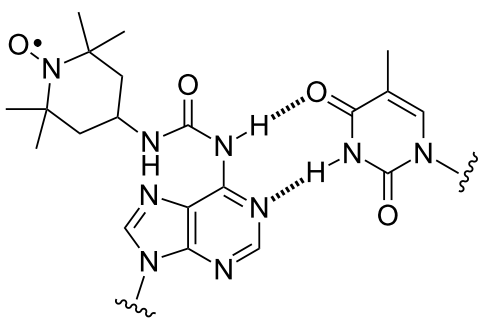

C<smiles></smiles>

$U_{A}$

$\mathrm{T}$

Figure 1: Base pairing of ${ }^{\top} C$ with $G(A),{ }^{\top} A$ with $T(B),{ }^{U} C$ with $G(C)$ and ${ }^{{ }} A$ with $T(D)$. 
spectra reveals subtle differences between the four base-pairing partners $\mathrm{A}, \mathrm{T}, \mathrm{G}$ and $\mathrm{C}$ when placed in a DNA duplex.

\section{Results and Discussion Synthesis of ${ }^{\top} \mathrm{A},{ }_{\mathrm{U}} \mathrm{A},{ }_{\mathrm{U}} \mathrm{C}$ and their corres- ponding phosphoramidites}

The spin-labeled nucleoside ${ }^{\mathrm{T}} \mathrm{A}$ and its corresponding phosphoramidite were prepared by a previously reported procedure [74] with minor modifications. The synthesis started with the reaction between 3',5'-diacetyl-2'-deoxyinosine (1) and 2,4,6triisopropylbenzenesulfonyl chloride to obtain compound 2 (Scheme 1). Coupling of 2 with 4 -amino-TEMPO gave 3 in good yields and deprotection of the acetyl groups gave ${ }^{\mathrm{T}} \mathrm{A}$, which was tritylated and phosphitylated to yield compounds $\mathbf{4}$ and $\mathbf{5}$, respectively.

For the synthesis of ${ }^{\mathrm{U}} \mathrm{A}, 3^{\prime}, 5^{\prime}$-TBDMS-protected 2'-deoxyadenosine [75] (6) was reacted with 4-isocyanato-TEMPO (7) $[64,76]$, which gave compound 8 in low yields (Scheme 2). Cleavage of the TBDMS groups using TBAF gave spin-labeled nucleoside ${ }^{\mathrm{U}} \mathrm{A}$, which was tritylated to give compound $\mathbf{9}$ and phosphitylated to give phosphoramidite $\mathbf{1 0}$.

The synthesis of ${ }^{\mathrm{U}} \mathrm{C}$, the urea-cytidine analogue, started by reaction of 3',5'-TBDMS-protected 2'-deoxycytidine (11) with 4-isocyanato-TEMPO (7) [64,76] to give 12 in good yields (Scheme 3). Removal of the TBDMS groups using TBAF gave spin-labeled nucleoside ${ }^{\mathrm{U}} \mathrm{C}$, which was tritylated to give com- pound 13 and subsequent phosphitylation yielded phosphoramidite 14.

\section{Synthesis and characterization of ${ }^{\mathrm{T}} \mathrm{A}-,{ }^{\mathrm{U}} \mathrm{A}$ - and ${ }^{\mathrm{U}} \mathrm{C}$-containing oligonucleotides}

The phosphoramidites of ${ }^{\mathrm{T}} \mathrm{A}(\mathbf{5}),{ }^{\mathrm{U}} \mathrm{A}(\mathbf{1 0})$ and ${ }^{\mathrm{U}} \mathrm{C}(\mathbf{1 4})$ were used to incorporate the spin-labeled nucleosides into DNA oligonucleotides using solid-phase synthesis [77]. The low stability of the nitroxide functional group in the TEMPO moiety towards acids lead to almost ca. 50\% reduction of the nitroxide during oligonucleotide synthesis, which utilized dichloroacetic acid for the removal of the trityl groups. However, in spite of low yields, the spin-labeled oligonucleotides were readily separated from those containing the reduced spin label by denaturing polyacrylamide gel electrophoresis. The incorporation of ${ }^{\mathrm{T}} \mathrm{A}, \mathrm{U}_{\mathrm{A}}$ and ${ }^{\mathrm{U}_{\mathrm{C}}}$ into DNA was confirmed by MALDI-TOF mass spectrometry (Table S1, Supporting Information File 1). Circular dichroism measurements showed that the incorporation of ${ }^{\mathrm{T}} \mathrm{A}, \mathrm{U}_{\mathrm{A}}$ and ${ }^{\mathrm{U}_{\mathrm{C}}}$ does not alter the B-DNA conformation of DNA duplexes containing these modifications (Figure S1, Supporting Information File 1).

The thermal denaturation studies indicated only a minor destabilization of DNA the duplexes when ${ }^{\mathrm{T}} \mathrm{A}$ was paired with $\mathrm{T}\left(T_{\mathrm{m}}\right.$ was only $2.7^{\circ} \mathrm{C}$ lower), compared to the natural nucleoside A (Table S2, Supporting Information File 1). The least stable base pairing was observed with the ${ }^{\mathrm{T}} \mathrm{A} \bullet \mathrm{A}$ mismatch, which showed destabilization by $8.2{ }^{\circ} \mathrm{C}$, compared to an $\mathrm{A} \bullet \mathrm{A}$ mismatch. The<smiles></smiles>

1

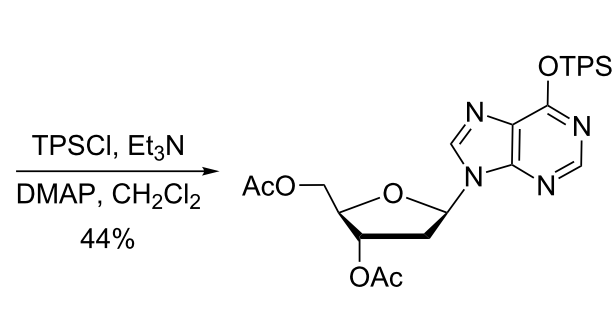

2<smiles></smiles>

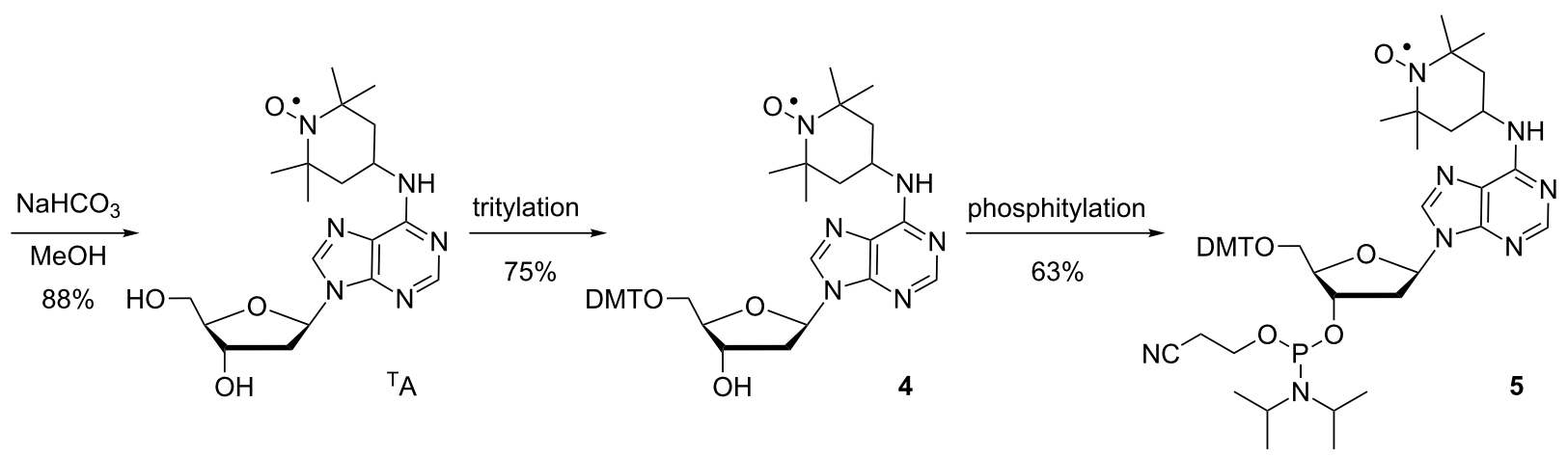



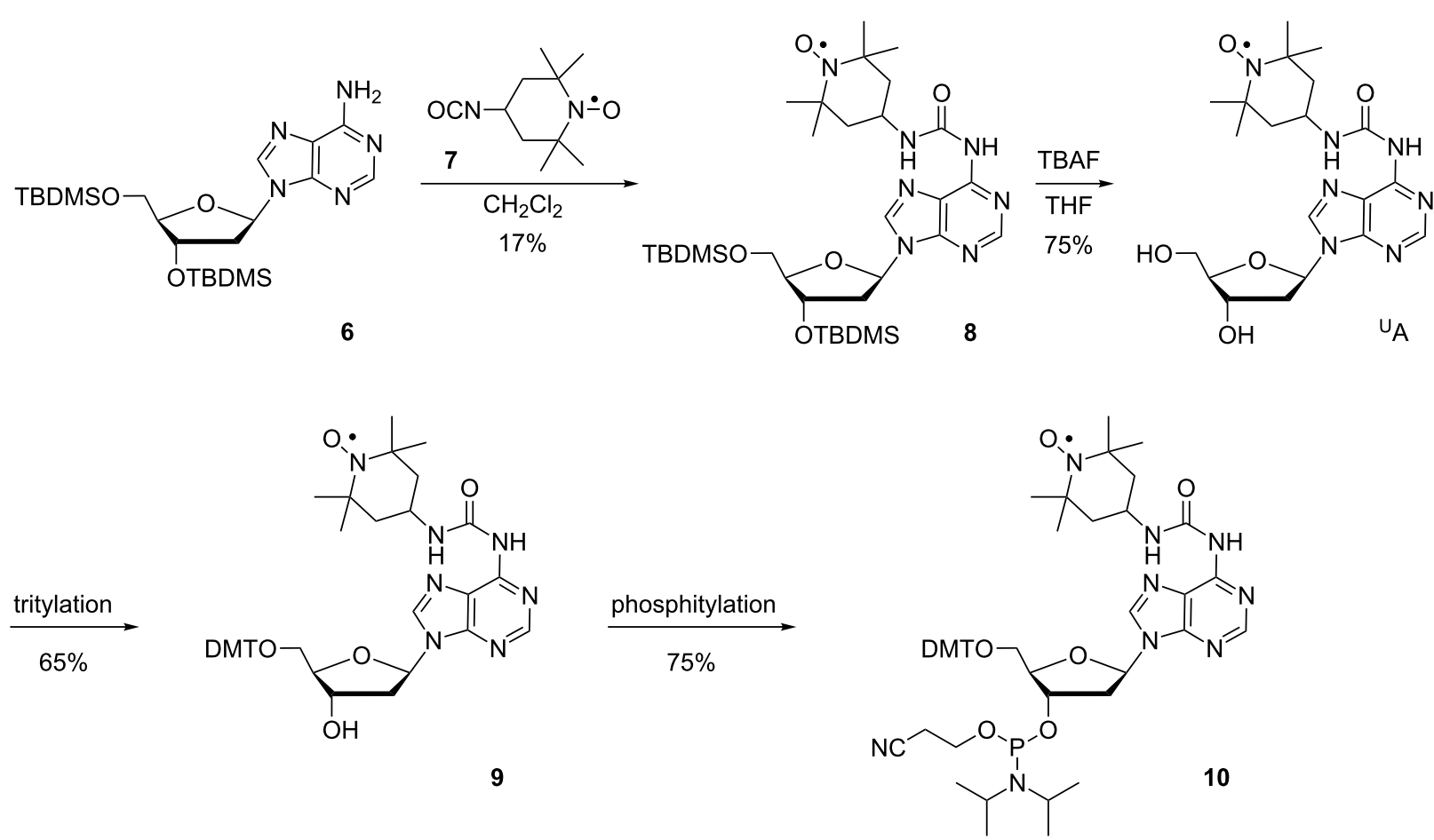

Scheme 2: Synthesis of nucleoside $\mathrm{U}_{\mathrm{A}}$ and its corresponding phosphoramidite 10.

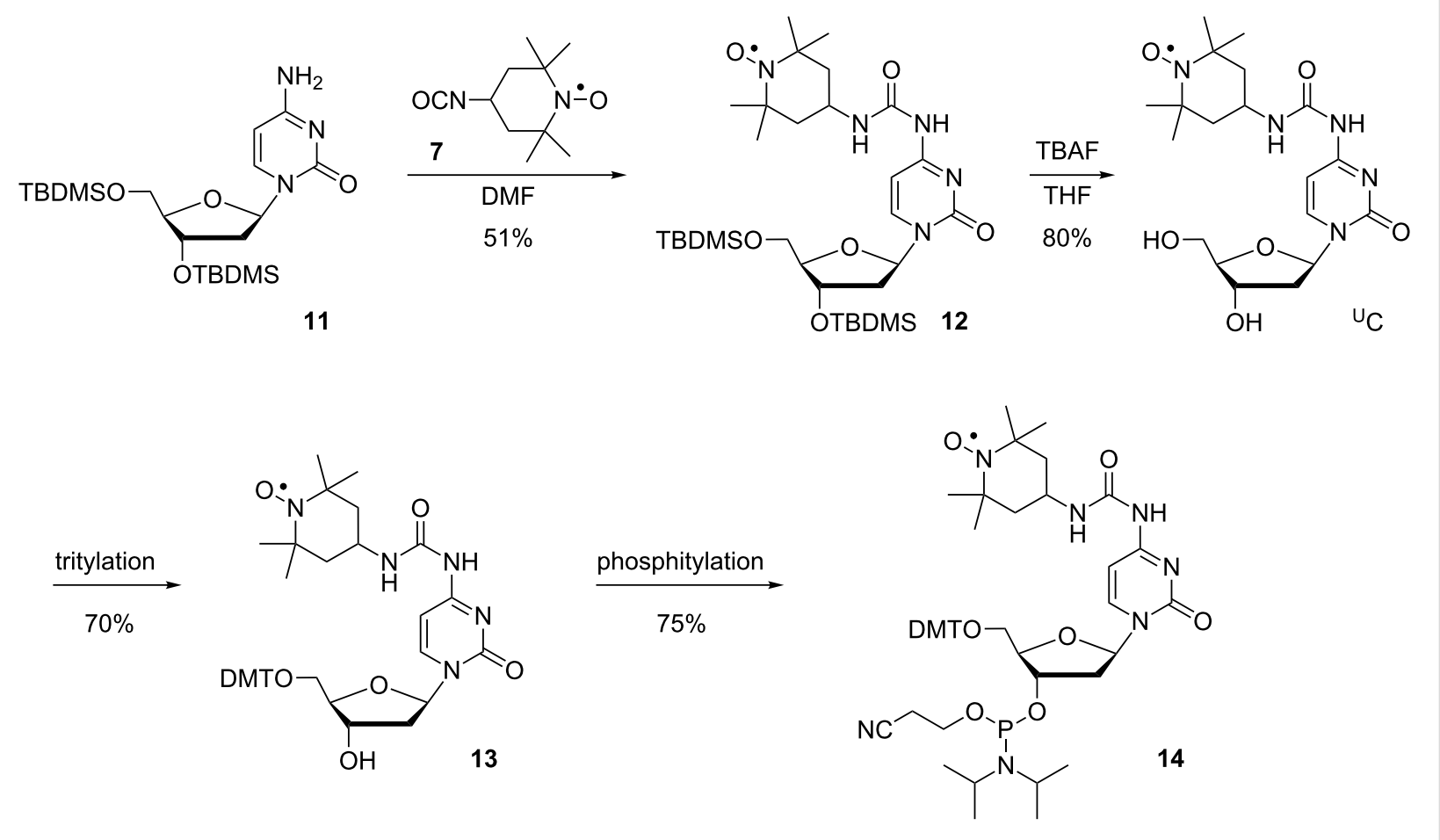

Scheme 3: Synthesis of nucleoside ${ }^{\mathrm{U}} \mathrm{C}$ and its corresponding phosphoramidite 14 . 
duplex stability order as a function of base-paring with ${ }^{\mathrm{T}} \mathrm{A}$ was ${ }^{\mathrm{T}} \mathrm{A} \cdot \mathrm{T}>{ }^{\mathrm{T}} \mathrm{A} \cdot \mathrm{G}>{ }^{\mathrm{T}} \mathrm{A} \cdot \mathrm{C}>{ }^{\mathrm{T}} \mathrm{A} \cdot \mathrm{A}$, consistent with the order of stability previously reported for A [48]. Replacing $\mathrm{C}$ with ${ }^{\mathrm{U}_{\mathrm{C}}}$ opposite $\mathrm{G}$ in a DNA duplex resulted in a $3.9^{\circ} \mathrm{C}$ decrease in the melting temperature $\left(T_{\mathrm{m}}\right)$ and a stability order of ${ }^{\mathrm{U}} \mathrm{C} \cdot \mathrm{G}>{ }^{\mathrm{U}} \mathrm{C} \cdot \mathrm{A}$ $>{ }^{\mathrm{U}} \cdot \mathrm{T}>{ }^{\mathrm{U}_{\mathrm{C}}} \cdot \mathrm{C}$ (Table $\mathrm{S} 3$, Supporting Information File 1). In contrast to ${ }^{\mathrm{T}} \mathrm{A}$ and ${ }^{\mathrm{U}_{\mathrm{C}}} \mathrm{C}, \mathrm{U}_{\mathrm{A}}$ had a large destabilizing effect on DNA duplexes (ca. $11^{\circ} \mathrm{C}$, Table S4, Supporting Information File 1). Interestingly, the melting temperatures of the DNA duplexes containing the base pairs ${ }^{\mathrm{U}} \mathrm{A} \cdot \mathrm{T},{ }^{\mathrm{U}} \mathrm{A} \cdot \mathrm{G}$ and ${ }^{\mathrm{U}} \mathrm{A} \bullet \mathrm{A}$ were nearly identical, whereas the ${ }^{\mathrm{U}} \mathrm{A} \cdot \mathrm{C}$ mismatch showed a further decrease in melting temperature of ca. $9^{\circ} \mathrm{C}$.

\section{EPR analysis of ${ }^{\top} \mathrm{A}-, \mathrm{U}_{\mathrm{C}}$-and $\mathrm{U}_{\mathrm{A}} \mathrm{A}$-labeled DNA duplexes}

To investigate the mobility of ${ }^{\mathrm{T}} \mathrm{A}$ in duplex DNA, we analyzed the EPR spectra of the four 14-mer DNA duplexes 5'-d(GACCTCG ${ }^{\mathrm{T}}$ AATCGTG)•5'-d(CACGATYCGAGGTC), where $\mathrm{Y}$ is either T, C, G or A (Figure 2). The EPR spectrum of the ${ }^{\mathrm{T}} \mathrm{A} \bullet \mathrm{T}$ pair was broadest, which is consistent with ${ }^{\mathrm{T}} \mathrm{A}$ forming a Watson-Crick base pair with $\mathrm{T}$, and thereby restricting the rotation around the C6-N6 bond through hydrogen bonding to N6, and consequently slowing the motion of the label (Figure 1B). On the other hand, the spectrum of ${ }^{\mathrm{T}} \mathrm{A} \cdot \mathrm{A}$ was the narrowest and thereby indicating the highest mobility, while the EPR spectrum of ${ }^{\mathrm{T}} \mathrm{A} \cdot \mathrm{G}$ was slightly broader than ${ }^{\mathrm{T}} \mathrm{A} \cdot \mathrm{A}$. Although base pairing schemes can be drawn for ${ }^{\mathrm{T}} \mathrm{A} \cdot \mathrm{G}$ and ${ }^{\mathrm{T}} \mathrm{A} \cdot \mathrm{A}$ that involve hydrogen bonding to $\mathrm{N} 6$ of ${ }^{\mathrm{T}} \mathrm{A}$ (Figure S2C and S2D, Supporting Information File 1) $[44,48,78-80]$, the increased mobility could be the result of the label being pushed further into the major groove of the DNA duplex, due to the space-demanding purine-purine pairs [81], where the spin-label mobility would be less affected by the local surroundings.

The mobility of ${ }^{\mathrm{T}} \mathrm{A} \cdot \mathrm{C}$ at $\mathrm{pH} 7$, as judged by its EPR spectrum (Figure 2A), was between that of ${ }^{\mathrm{T}} \mathrm{A} \cdot \mathrm{T}$ and ${ }^{\mathrm{T}} \mathrm{A} \cdot \mathrm{G}$. Previous NMR studies of the ${ }^{\mathrm{T}} \mathrm{A} \cdot \mathrm{C}$ mismatch at $\mathrm{pH} 8.5$ [47] and 8.9 [82] showed one hydrogen bond, located between $\mathrm{N} 6$ of ${ }^{\mathrm{T}} \mathrm{A}$ and $\mathrm{N} 3$ of cytidine (Figure $\mathrm{S} 2 \mathrm{~B}$, Supporting Information File 1). If ${ }^{\mathrm{T}} \mathrm{A}$ is protonated on $\mathrm{N} 1$ to form ${ }^{\mathrm{T}} \mathrm{AH}^{+}$, it could form a wobble-pair with $\mathrm{C}[47,83]$ (Figure 3A), which would be expected to decrease the mobility of the spin label. The apparent $\mathrm{p} K_{\mathrm{a}}$ of the proton on $\mathrm{N} 1$ has been determined by NMR studies to be 7.2 [47], which means that more than half of the ${ }^{\mathrm{T}} \mathrm{A} \cdot \mathrm{C}$ pairs would be protonated at $\mathrm{pH}$ 7. To explore if further reduction in mobility (due to conversion of the ${ }^{\mathrm{T}} \mathrm{A} \cdot \mathrm{C}$ pair to the ${ }^{\mathrm{T}} \mathrm{AH}^{+} \cdot \mathrm{C}$ pair) would be detected by EPR, its spectrum was also recorded at $\mathrm{pH} 5$ (Figure 2B). Indeed, comparison of the EPR spectra of ${ }^{\mathrm{T}} \mathrm{A} \cdot \mathrm{C}$ at $\mathrm{pH} 5$ and $\mathrm{pH} 7$ clearly shows further broadening at the lower $\mathrm{pH}$, almost to that of the ${ }^{\mathrm{T}} \mathrm{A} \bullet \mathrm{T}$ pair, and is consistent with the formation of the ${ }^{\mathrm{T}} \mathrm{AH}^{+} \cdot \mathrm{C}$ pair.

The ${ }^{\mathrm{T}} \mathrm{A} \cdot \mathrm{T}$ and ${ }^{\mathrm{T}} \mathrm{A} \cdot \mathrm{A}$ pairs had similar EPR spectra at $\mathrm{pH} 7$ and 5 (Figure 2B). However, significant broadening was observed in the EPR spectrum of the ${ }^{\mathrm{T}} \mathrm{A} \cdot \mathrm{G}$ mismatch at $\mathrm{pH}$ 5. In fact, the spectrum of ${ }^{\mathrm{T}} \mathrm{A} \cdot \mathrm{G}$ is nearly superimposable to that of the ${ }^{\mathrm{T}} \mathrm{A} \cdot \mathrm{T}$ pair, indicating reduction in mobility due to formation of another hydrogen bond at $\mathrm{pH}$ 5. Studies by NMR and X-ray crystallography have shown that ${ }^{\mathrm{T}} \mathrm{AH}^{+} \cdot \mathrm{G}$ pairs form when ${ }^{\mathrm{T}} \mathrm{A} \cdot \mathrm{G}$ mismatches are incubated at $\mathrm{pH}$ below 5.6 , in which the $\mathrm{G}$ has flipped into a syn conformation and the O6 and N7 form

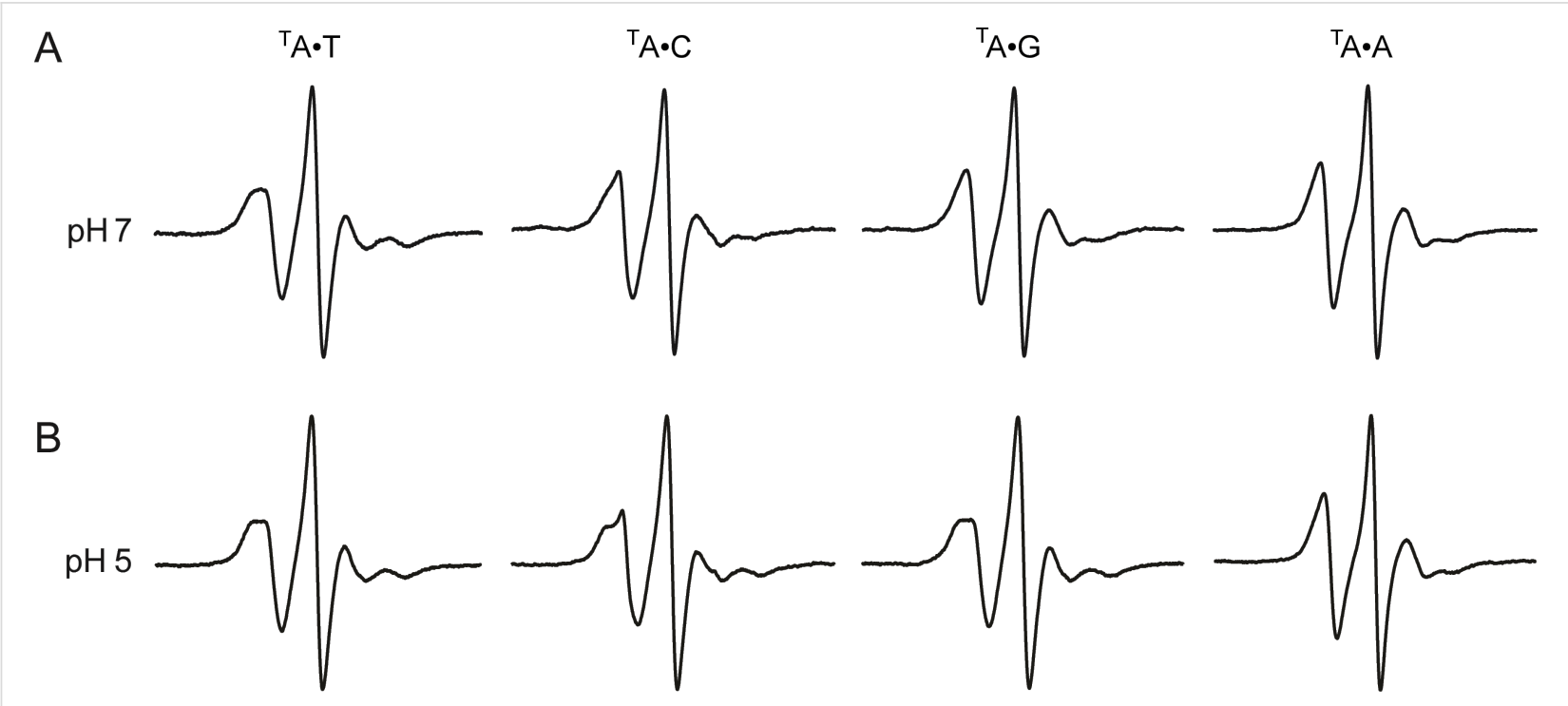

Figure 2: EPR spectra of 14-mer DNA duplexes 5'-d(GACCTCG ${ }^{\top}$ AATCGTG)·5'-d(CACGATYCGAGGTC), (10 mM phosphate, $100 \mathrm{mM} \mathrm{NaCl,} 0.1 \mathrm{mM}$ $\mathrm{Na}_{2}$ EDTA, pH $7.0(\mathrm{~A})$ and $\left.5.0(\mathrm{~B})\right)$ at $10^{\circ} \mathrm{C}$, where ${ }^{\mathrm{T}} \mathrm{A}$ is paired with either $\mathrm{Y}=\mathrm{T}, \mathrm{C}, \mathrm{G}$ or $\mathrm{A}$. 
A

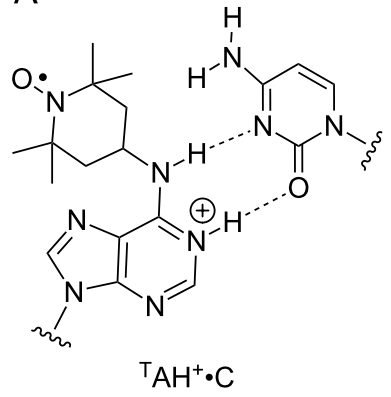

B<smiles></smiles>

Figure 3: Possible base pairing of ${ }^{\top} \mathrm{AH}^{+}$with $\mathrm{C}(\mathrm{A})$ and $\mathrm{G}(\mathrm{B})$ at $\mathrm{pH} 5$.

Hoogsteen hydrogen bonds (Figure 3B) [43,44,78]. Thus, the formation of the ${ }^{\mathrm{T}} \mathrm{AH}^{+} \cdot \mathrm{G}$ pair can be readily detected by EPR spectroscopy.

Nucleosides ${ }^{\mathrm{U}_{\mathrm{A}}}$ and ${ }^{\mathrm{U}} \mathrm{C}$, the new and readily prepared spin labels that are described here, contain a stable urea linkage that provides additional hydrogen-bonding possibilities. In particular, pairing of ${ }^{\mathrm{U}} \mathrm{A}$ and ${ }^{\mathrm{U}} \mathrm{C}$ to $\mathrm{C}$, which has been shown by NMR to form a hydrogen bond between its $\mathrm{N} 3$ and the proton on N6 of $\mathrm{A}$ [83] as well as $\mathrm{N} 4$ of $\mathrm{C}[69,84]$, should enable the oxygen in the urea moiety of both ${ }^{\mathrm{U}} \mathrm{A}$ and ${ }^{\mathrm{U}} \mathrm{C}$ to pair with a $\mathrm{N} 4$ proton of $\mathrm{C}$ (Figure 4A and B). Such hydrogen bonding should have an effect on the spin label mobility and be manifested in the line width of the EPR spectra.

Therefore, we recorded the EPR spectra of duplexes 5'-d(GACCTCGXATCGTG)•5'-d(CACGATYCGAGGTC), where $\mathrm{X}$ is either ${ }^{\mathrm{U}} \mathrm{A}$ or ${ }^{\mathrm{U}} \mathrm{C}$, and $\mathrm{Y}$ is either $\mathrm{C}, \mathrm{A}, \mathrm{G}$ or $\mathrm{T}$ (Figure 5). Indeed, the lowest mobility, i.e., the widest spectra was observed for both ${ }^{\mathrm{U}} \mathrm{A} \cdot \mathrm{C}$ and ${ }^{\mathrm{U}} \mathrm{C} \cdot \mathrm{C}$, providing circumstantial evidence for hydrogen bonding of $\mathrm{C}$ to the urea linkage. Interestingly, the same mobility order was observed for both ${ }^{\mathrm{U}_{\mathrm{A}}}$ and ${ }^{\mathrm{U}} \mathrm{C}: \mathrm{X} \bullet \mathrm{C}<\mathrm{X} \bullet \mathrm{A} \leq \mathrm{X} \bullet \mathrm{G}<\mathrm{X} \bullet \mathrm{T}$. Pairing with $\mathrm{T}$ resulted in a high mobility for both ${ }^{\mathrm{U}_{\mathrm{A}}}$ and ${ }^{\mathrm{U}} \mathrm{C}$, whereas pairing with either A or $\mathrm{G}$, caused mobility intermediate between that of $\mathrm{C}$ and $\mathrm{T}$. As expected, the EPR spectra of the duplexes containing the urea-linked spin labels $\left({ }^{\mathrm{U}_{\mathrm{A}}}\right.$ and ${ }^{\mathrm{U}} \mathrm{C}$ ) were narrower than for the N6-TEMPO-dA $\left({ }^{\mathrm{T}} \mathrm{A}\right)$ labeled duplexes. The extended urea linker not only contains more rotatable single bonds but also projects the spin label further out of the major groove, where it is less constrained sterically by the DNA.

\section{Conclusion}

Three spin-labeled deoxynucleosides, ${ }^{\mathrm{T}} \mathrm{A},{ }^{\mathrm{U}} \mathrm{A}$ and ${ }^{\mathrm{U}} \mathrm{C}$, were prepared and incorporated into oligonucleotides by the phosphoramidite method. While ${ }^{\mathrm{U}} \mathrm{A}$ resulted in a major decrease in the melting temperature of a DNA duplex when incorporated opposite to $\mathrm{C}, \mathrm{CD}$ measurements revealed that all three spin labels were accommodated in a B-form DNA duplex. The mobility of the spin label ${ }^{\mathrm{T}} \mathrm{A}$ was highly base-pair sensitive, allowing detection of its respective base-pairing partner in duplex DNA. Moreover, the mobility of ${ }^{\mathrm{T}} \mathrm{A}$ was significantly reduced when paired with $\mathrm{C}$ or $\mathrm{G}$ in a DNA duplex at $\mathrm{pH} 5$. This finding is consistent with protonation of ${ }^{\mathrm{T}} \mathrm{A}$ and subsequent participation of the proton in hydrogen-bonding with $\mathrm{C}$ and $\mathrm{G}$. The urea-linked ${ }^{\mathrm{U}} \mathrm{A}$ and ${ }^{\mathrm{U}} \mathrm{C}$ spin labels showed a similar
A

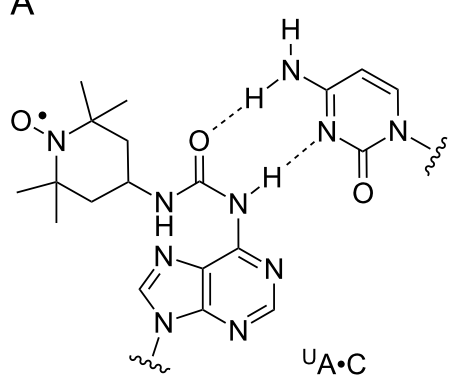

B

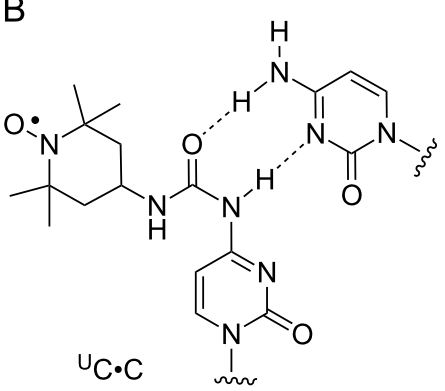

Figure 4: Possible base pairing of ${ }^{\mathrm{U}} \mathrm{A}$ and ${ }^{\mathrm{U}} \mathrm{C}$ with $\mathrm{C}$. 


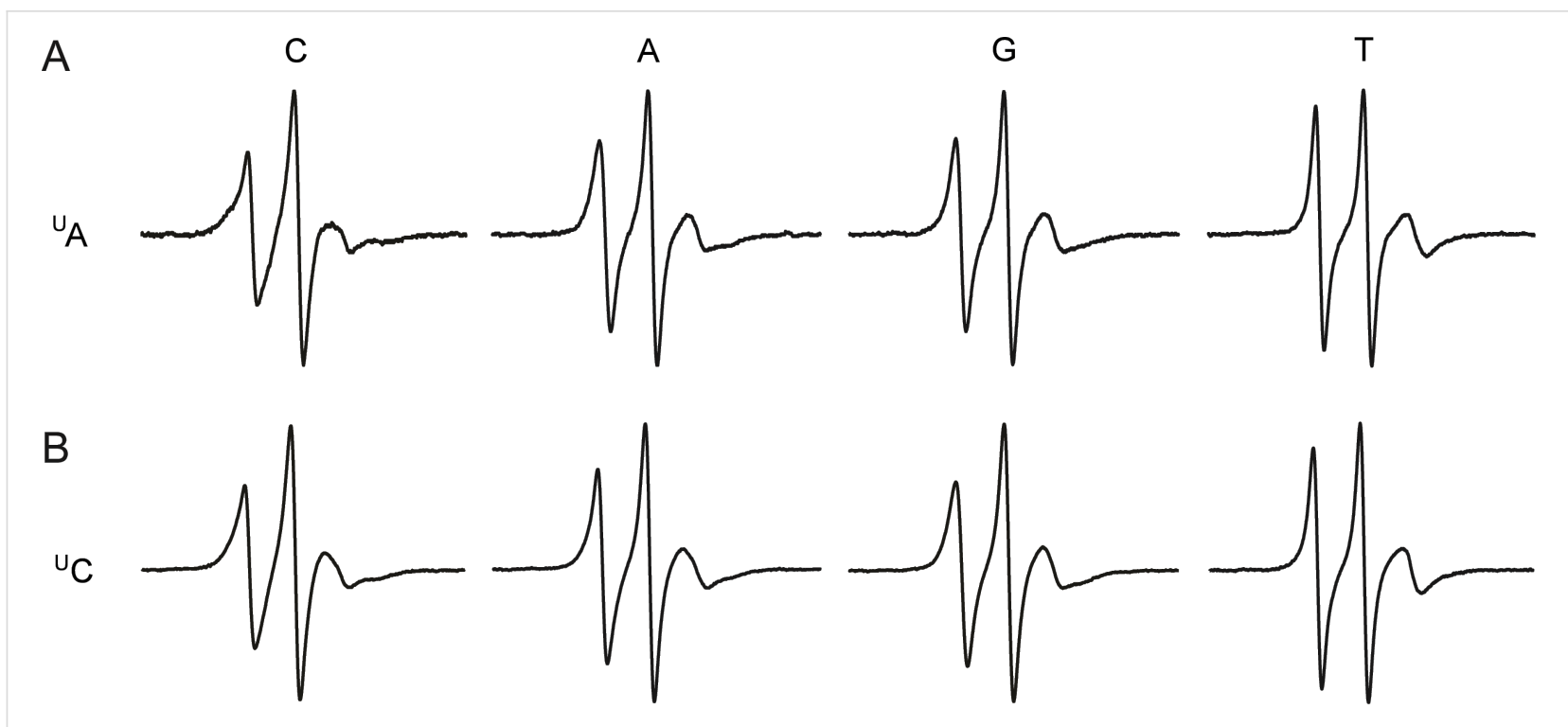

Figure 5: EPR spectra of 14-mer DNA duplex 5'-d(GACCTCG UATCGTG)·5'-d(CACGATYCGAGGTC) (A), and 5'-d(GACCTCG UCATCGTG) •5'd(CACGATYCGAGGTC) (B), (10 mM phosphate, $\left.100 \mathrm{mM} \mathrm{NaCl}, 0.1 \mathrm{mM} \mathrm{Na}_{2} E D T A, p H 7.0\right)$ at $10{ }^{\circ} \mathrm{C}$, where ${ }^{\mathrm{U}} \mathrm{A}$ or ${ }^{\cup} \mathrm{C}$ is paired with either $\mathrm{Y}=\mathrm{T}, \mathrm{C}, \mathrm{G}$ or $\mathrm{A}$.

mobility order when paired with A, G, C or T in a DNA duplex, with the lowest mobility when paired with $\mathrm{C}$ and the highest for $\mathrm{T}$. These results show that the three labels, in particular ${ }^{\mathrm{T}} \mathrm{A}$, can report minor changes in their microenvironment, such as protonation, when placed in structured regions of nucleic acids.

\section{Supporting Information}

\section{Supporting Information File 1 \\ Experimental part. \\ [http://www.beilstein-journals.org/bjoc/content/ supplementary/1860-5397-11-24-S1.pdf]}

\section{Acknowledgements}

We thank the Icelandic Research Fund and the University of Iceland Research Fund for financial support. We thank Dr. Pavol Cekan for technical assistance, Dr. Sigridur Jonsdottir for NMR and MS analyses and the members of the Sigurdsson research group for helpful discussions.

\section{References}

1. Jacobo-Molina, A.; Ding, J.; Nanni, R. G.; Clark, A. D., Jr.; Lu, X.; Tantillo, C.; Williams, R. L.; Kamer, G.; Ferris, A. L.; Clark, P. Proc. Natl. Acad. Sci. U. S. A. 1993, 90, 6320-6324.

2. Laughlan, G.; Murchie, A.; Norman, D. G.; Moore, M. H.; Moody, P. C.; Lilley, D. M.; Luisi, B. Science 1994, 265, 520-524. doi:10.1126/science.8036494

3. Holbrook, S. R.; Holbrook, E. L.; Walukiewicz, H. E. Cell. Mol. Life Sci. 2001, 58, 234-243. doi:10.1007/pl00000851
4. Vassylyev, D. G.; Sekine, S.-i.; Laptenko, O.; Lee, J.; Vassylyeva, M. N.; Borukhov, S.; Yokoyama, S. Nature 2002, 417, 712-719. doi:10.1038/nature752

5. Edwards, T. E.; Klein, D. J.; Ferré-D'Amaré, A. R. Curr. Opin. Struct. Biol. 2007, 17, 273-279. doi:10.1016/j.sbi.2007.05.004

6. Mooers, B. H. M. Methods 2009, 47, 168-176. doi:10.1016/j.ymeth.2008.09.006

7. Clore, G. M.; Gronenborn, A. M. Curr. Opin. Chem. Biol. 1998, 2, 564-570. doi:10.1016/s1367-5931(98)80084-7

8. Brutscher, B.; Boisbouvier, J.; Pardi, A.; Marion, D.; Simorre, J.-P. J. Am. Chem. Soc. 1998, 120, 11845-11851. doi:10.1021/ja982853।

9. Tjandra, N. Structure 1999, 7, R205-R211.

10. Riek, R.; Pervushin, K.; Wüthrich, K. Trends Biochem. Sci. 2000, 25 462-468. doi:10.1016/S0968-0004(00)01665-0

11. Latham, M. P.; Brown, D. J.; McCallum, S. A.; Pardi, A. ChemBioChem 2005, 6, 1492-1505. doi:10.1002/cbic.200500123

12. Campagne, S.; Gervais, V.; Milon, A. J. R. Soc., Interface 2011, 8 , 1065-1078. doi:10.1098/rsif.2010.0543

13. Wu, P. G.; Brand, L. Anal. Biochem. 1994, 218, 1-13. doi:10.1006/abio.1994.1134

14. Prisner, T.; Rohrer, M.; MacMillan, F. Annu. Rev. Phys. Chem. 2001, 52, 279-313. doi:10.1146/annurev.physchem.52.1.279

15. Schiemann, O.; Piton, N.; Mu, Y.; Stock, G.; Engels, J. W.; Prisner, T. F. J. Am. Chem. Soc. 2004, 126, 5722-5729. doi:10.1021/ja0393877

16. Bowman, M. K.; Maryasov, A. G.; Kim, N.; DeRose, V. J. Appl. Magn. Reson. 2004, 26, 23-39. doi:10.1007/BF03166560

17. Kim, N.-K.; Murali, A.; DeRose, V. J. Chem. Biol. 2004, 11, 939-948. doi:10.1016/j.chembiol.2004.04.013

18. Piton, N.; Schiemann, O.; Mu, Y.; Stock, G.; Prisner, T.; Engels, J. W. Nucleosides, Nucleotides Nucleic Acids 2005, 24, 771-775. doi:10.1081/NCN-200060139

19. Sabanayagam, C. R.; Eid, J. S.; Meller, A. J. Chem. Phys. 2005, 122, 061103. doi:10.1063/1.1854120 
20. Schiemann, O.; Piton, N.; Plackmeyer, J.; Bode, B. E.; Prisner, T. F.; Engels, J. W. Nat. Protoc. 2007, 2, 904-923.

doi:10.1038/nprot.2007.97

21. Schiemann, O.; Prisner, T. F. Q. Rev. Biophys. 2007, 40, 1-53. doi:10.1017/S003358350700460X

22. Sicoli, G.; Mathis, G.; Delalande, O.; Boulard, Y.; Gasparutto, D.; Gambarelli, S. Angew. Chem. 2008, 120, 747-749. doi:10.1002/ange.200704133

23. Xie, Y.; Dix, A. V.; Tor, Y. J. Am. Chem. Soc. 2009, 131, 17605-17614. doi:10.1021/ja905767g

24. Sicoli, G.; Wachowius, F.; Bennati, M.; Höbartner, C. Angew. Chem., Int. Ed. 2010, 49, 6443-6447. doi:10.1002/anie.201000713

25. Kim, N.-K.; Bowman, M. K.; DeRose, V. J. J. Am. Chem. Soc. 2010, 132, 8882-8884. doi:10.1021/ja101317g

26. Ding, P.; Wunnicke, D.; Steinhoff, H.-J.; Seela, F. Chem. - Eur. J. 2010, 16, 14385-14396. doi:10.1002/chem.201001572

27. Stoller, S.; Sicoli, G.; Baranova, T. Y.; Bennati, M.; Diederichsen, U. Angew. Chem., Int. Ed. 2011, 50, 9743-9746. doi:10.1002/anie.201103315

28. Marko, A.; Denysenkov, V.; Margraf, D.; Cekan, P.; Schiemann, O.; Sigurdsson, S. T.; Prisner, T. F. J. Am. Chem. Soc. 2011, 133, 13375-13379. doi:10.1021/ja201244u

29. Hengesbach, M.; Kim, N.-K.; Feigon, J.; Stone, M. D. Angew. Chem., Int. Ed. 2012, 51, 5876-5879. doi:10.1002/anie.201200526

30. Pornsuwan, S.; Giller, K.; Riedel, D.; Becker, S.; Griesinger, C.; Bennati, M. Angew. Chem., Int. Ed. 2013, 52, 10290-10294. doi:10.1002/anie.201304747

31. Polyhach, Y.; Godt, A.; Bauer, C.; Jeschke, G. J. Magn. Reson. 2007, 185, 118-129. doi:10.1016/j.jmr.2006.11.012

32. Bode, B. E.; Plackmeyer, J.; Prisner, T. F.; Schiemann, O. J. Phys. Chem. A 2008, 112, 5064-5073. doi:10.1021/jp710504k

33. Schiemann, O.; Cekan, P.; Margraf, D.; Prisner, T. F.; Sigurdsson, S. T. Angew. Chem., Int. Ed. 2009, 48, 3292-3295. doi:10.1002/anie.200805152

34. Marko, A.; Margraf, D.; Cekan, P.; Sigurdsson, S. T.; Schiemann, O.; Prisner, T. F. Phys. Rev. E 2010, 81, 021911. doi:10.1103/PhysRevE.81.021911

35. Tkach, I.; Pornsuwan, S.; Höbartner, C.; Wachowius, F.; Sigurdsson, S. T.; Baranova, T. Y.; Diederichsen, U.; Sicoli, G.; Bennati, M. Phys. Chem. Chem. Phys. 2013, 15, 3433-3437. doi:10.1039/C3CP44415E

36. Svergun, D. I.; Koch, M. H. J. Rep. Prog. Phys. 2003, 66, 1735. doi:10.1088/0034-4885/66/10/R05

37. Lipfert, J.; Doniach, S. Annu. Rev. Biophys. Biomol. Struct. 2007, 36, 307-327. doi:10.1146/annurev.biophys.36.040306.132655

38. Bernadó, P.; Mylonas, E.; Petoukhov, M. V.; Blackledge, M.; Svergun, D. I. J. Am. Chem. Soc. 2007, 129, 5656-5664. doi:10.1021/ja069124n

39. Mertens, H. D. T.; Svergun, D. I. J. Struct. Biol. 2010, 172, 128-141. doi:10.1016/j.jsb.2010.06.012

40. Zıdek, L.; Štefl, R.; Sklenář, V. Curr. Opin. Struct. Biol. 2001, 11, 275-281. doi:10.1016/S0959-440X(00)00218-9

41. Fürtig, B.; Richter, C.; Wöhnert, J.; Schwalbe, H. ChemBioChem 2003, 4, 936-962. doi:10.1002/cbic.200300700

42. Al-Hashimi, H. M. J. Magn. Reson. 2013, 237, 191-204. doi:10.1016/j.jmr.2013.08.014

43. Gao, X.; Patel, D. J. J. Am. Chem. Soc. 1988, 110, 5178-5182. doi:10.1021/ja00223a045
44. Lane, A.; Jenkins, T.; Brown, D.; Brown, T. Biochem. J. 1991, 279, 269-281.

45. Maskos, K.; Gunn, B. M.; LeBlanc, D. A.; Morden, K. M. Biochemistry 1993, 32, 3583-3595. doi:10.1021/bi00065a009

46. Lane, A.; Ebel, S.; Brown, T. Eur. J. Biochem. 1994, 220, 717-727. doi:10.1111/j.1432-1033.1994.tb18672.x

47. Boulard, Y.; Cognet, J. A. H.; Gabarro-Arpa, J.; Le Bret, M.; Carbonnaux, C.; Fazakerley, G. V. J. Mol. Biol. 1995, 246, 194-208. doi:10.1006/jmbi.1994.0076

48. Peyret, N.; Seneviratne, P. A.; Allawi, H. T.; SantaLucia, J., Jr. Biochemistry 1999, 38, 3468-3477. doi:10.1021/bi9825091

49. Rist, M.; Marino, J. Nucleic Acids Res. 2001, 29, 2401-2408. doi:10.1093/nar/29.11.2401

50. Liu, C.; Martin, C. T. J. Mol. Biol. 2001, 308, 465-475. doi:10.1006/jmbi.2001.4601

51. Cekan, P.; Sigurdsson, S. T. Chem. Commun. 2008, 3393-3395. doi: $10.1039 / \mathrm{b} 801833 \mathrm{~b}$

52. Sinkeldam, R. W.; Greco, N. J.; Tor, Y. Chem. Rev. 2010, 110, 2579-2619. doi:10.1021/cr900301e

53. Wilhelmsson, L. M. Q. Rev. Biophys. 2010, 43, 159-183. doi:10.1017/S0033583510000090

54. Gardarsson, H.; Sigurdsson, S. T. Bioorg. Med. Chem. 2010, 18, 6121-6126. doi:10.1016/j.bmc.2010.06.060

55. Shin, D.; Sinkeldam, R. W.; Tor, Y. J. Am. Chem. Soc. 2011, 133, 14912-14915. doi:10.1021/ja206095a

56. Gardarsson, H.; Kale, A. S.; Sigurdsson, S. T. ChemBioChem 2011, 12, 567-575. doi:10.1002/cbic.201000478

57. Dierckx, A.; Miannay, F.-A.; Ben Gaied, N.; Preus, S.; Björck, M.; Brown, T.; Wilhelmsson, L. M. Chem. - Eur. J. 2012, 18, 5987-5997. doi:10.1002/chem.201103419

58. Saito, Y.; Miyauchi, Y.; Okamoto, A.; Saito, I. Tetrahedron Lett. 2004, 45, 7827-7831. doi:10.1016/j.tetlet.2004.09.003

59. Xie, Y.; Maxson, T.; Tor, Y. Org. Biomol. Chem. 2010, 8, 5053-5055. doi:10.1039/C0OB00413H

60. Sankaran, N. B.; Sato, Y.; Sato, F.; Rajendar, B.; Morita, K.; Seino, T.; Nishizawa, S.; Teramae, N. J. Phys. Chem. B 2009, 113, 1522-1529. doi:10.1021/jp808576t

61. Gislason, K.; Gophane, D. B.; Sigurdsson, S. T. Org. Biomol. Chem. 2013, 11, 149-157. doi:10.1039/c2ob26536b

62. Haller, A.; Rieder, U.; Aigner, M.; Blanchard, S. C.; Micura, R. Nat. Chem. Biol. 2011, 7, 393-400. doi:10.1038/nchembio.562

63. Haller, A.; Altman, R. B.; Soulière, M. F.; Blanchard, S. C.; Micura, R. Proc. Natl. Acad. Sci. U. S. A. 2013, 110, 4188-4193. doi:10.1073/pnas.1218062110

64. Edwards, T. E.; Okonogi, T. M.; Robinson, B. H.; Sigurdsson, S. T. J. Am. Chem. Soc. 2001, 123, 1527-1528. doi:10.1021/ja005649i

65. Qin, P. Z.; Butcher, S. E.; Feigon, J.; Hubbell, W. L. Biochemistry 2001, 40, 6929-6936. doi:10.1021/bi010294g

66. Qin, P. Z.; Hideg, K.; Feigon, J.; Hubbell, W. L. Biochemistry 2003, 42, 6772-6783. doi:10.1021/bi027222p

67. Sowa, G. Z.; Qin, P. Z. Prog. Nucleic Acid Res. Mol. Biol. 2008, 82, 147-197. doi:10.1016/s0079-6603(08)00005-6

68. Zhang, X.; Cekan, P.; Sigurdsson, S. T.; Qin, P. Z. Methods Enzymol. 2009, 469, 303-328. doi:10.1016/s0076-6879(09)69015-7

69. Cekan, P.; Sigurdsson, S. T. J. Am. Chem. Soc. 2009, 131, 18054-18056. doi:10.1021/ja905623k

70. Ricci, A.; Marinello, J.; Bortolus, M.; Sánchez, A.; Grandas, A.; Pedroso, E.; Pommier, Y.; Capranico, G.; Maniero, A. L.; Zagotto, G. J. Med. Chem. 2011, 54, 1003-1009. doi:10.1021/jm101232t 
71. Höbartner, C.; Sicoli, G.; Wachowius, F.; Gophane, D. B.; Sigurdsson, S. T. J. Org. Chem. 2012, 77, 7749-7754. doi:10.1021/jo301227w

72. Nguyen, P.; Qin, P. Z. Wiley Interdiscip. Rev.: RNA 2012, 3, 62-72. doi:10.1002/wrna.104

73. Gophane, D. B.; Sigurdsson, S. T. Chem. Commun. 2013, 49, 999-1001. doi:10.1039/c2cc36389e

74. Giordano, C.; Fratini, F.; Attanasio, D.; Cellai, L. Synthesis 2001, 565-572. doi:10.1055/s-2001-12355

75. Chen, L. S.; Bahr, M. H.; Sheppard, T. L. Bioorg. Med. Chem. Lett. 2003, 13, 1509-1512. doi:10.1016/S0960-894X(03)00204-X

76. Zakrzewski, J.; Krawczyk, M. Heteroat. Chem. 2006, 17, 393-401. doi:10.1002/hc. 20228

77. Cekan, P.; Smith, A. L.; Barhate, N.; Robinson, B. H.; Sigurdsson, S. T. Nucleic Acids Res. 2008, 36, 5946-5954. doi:10.1093/nar/gkn562

78. Brown, T.; Leonard, G. A.; Booth, E. D.; Chambers, J. J. Mol. Biol. 1989, 207, 455-457. doi:10.1016/0022-2836(89)90268-4

79. Brown, T.; Leonard, G. A.; Booth, E. D.; Kneale, G. J. Mol. Biol. 1990, 212, 437-440. doi:10.1016/0022-2836(90)90320-L

80. Leonard, G. A.; Booth, E. D.; Brown, T. Nucleic Acids Res. 1990, 18, 5617-5623. doi:10.1093/nar/18.19.5617

81. Brown, T. Aldrichimica Acta 1995, 28, 15-20.

82. Boulard, Y.; Cognet, J. A. H.; Gabarro-Arpa, J.; Le Bret, M.; Sowers, L.; Fazakerley, G. V. Nucleic Acids Res. 1992, 20, 1933-1941. doi:10.1093/nar/20.8.1933

83. Allawi, H. T.; SantaLucia, J., Jr.. Biochemistry 1998, 37, 9435-9444. doi:10.1021/bi9803729

84. Boulard, Y.; Cognet, J. A. H.; Fazakerley, G. V. J. Mol. Biol. 1997, 268, 331-347. doi:10.1006/jmbi.1997.0975

\section{License and Terms}

This is an Open Access article under the terms of the Creative Commons Attribution License (http://creativecommons.org/licenses/by/2.0), which permits unrestricted use, distribution, and reproduction in any medium, provided the original work is properly cited.

The license is subject to the Beilstein Journal of Organic Chemistry terms and conditions:

(http://www.beilstein-journals.org/bjoc)

The definitive version of this article is the electronic one which can be found at: doi:10.3762/bjoc. 11.24 